\title{
Cost of Energy Input in the Production of Cassava (Manihot Esculenta)
}

\author{
Babajide S. Kosemani ${ }^{1} \&$ A. Isaac Bamgboye ${ }^{2}$ \\ ${ }^{1}$ Department of Agricultural Engineering, Federal College of Agriculture, Ibadan, Oyo State, Nigeria \\ ${ }^{2}$ Department of Agricultural and Environmental Engineering, University of Ibadan, Ibadan, Oyo State, Nigeria \\ Correspondence: Babajide S. Kosemani, Department of Agricultural Engineering, Federal College of Agriculture, \\ Ibadan, Oyo State, Nigeria. Tel: 234-803-464-8673. E-mail: indizjiddy@yahoo.com
}

Received: February 26, 2018

Accepted: March 7, 2018

Online Published: March 23, 2018

doi:10.5539/eer.v8n1p10

URL: https://doi.org/10.5539/eer.v8n1p10

\begin{abstract}
The economic analysis of input energy in cassava production was considered in this study. Farms were surveyed to collect data on fuel, natural gas, fertilizer, pesticides and chemicals used on the farm for cassava production. The areas of study were Oyo, Ogun, Osun and Kwara States of Nigeria. The data for cost input resources in all the selected farms during cassava production from land preparation to transportation to market or house was obtained using structured questionnaire and oral interviews. Mathematical expressions were developed to evaluate cost analysis for each of the defined unit operations and the cost incurred were then determined. The total cost of production of one hectare of cassava was $\$ 82,055$ and cost analysis revealed that profit of production of one hectare of cassava was $\$ 123,745$. Benefit cost ratio was 2.50, which was greater than 1.0, indicating that cassava production is feasible from the economic stand point.
\end{abstract}

Keywords: cost analysis, benefit cost ratio, energy, cassava

\section{Introduction}

Cassava (Maninot esculenta) is a drought-tolerant, perennial woody shrub and staple food crop with up to $32 \%$ (fresh) starch content which is cultivated extensively as a food crop in Africa, (Bamgboye and Kosemani, 2015; Shubo et al., 2017). In terms of production, it ranked as the fifth most important crop in the world after maize, rice, wheat and potato but ranked first in sub-Saharan Africa (Ralf, 2010). Nigeria is the world's leading cassava producer with about 19 percent share in the global market (FAO 2013). In African, over 103 million metric tons of cassava is produced annually, while Nigeria production accounted for approximately 34 percent (35 million metric tons) of Africa's output (FAO, 2015). In spite of this volume, the full yield potential has not been realized since smallholder production rarely exceeds 11 MT per hectare, and most of the commercial/industrial cassava processors face a critical supply constraint. In fact, many commercial cassava agri-businesses operate below processing capacity due to the irregular supply of fresh cassava roots (USAID, 2015).

Cassava utilization patterns vary considerably in different parts of the world (Onyenwoke and Simonyan, 2014). Presently in Africa, 90 percent of cassava produced is consumed as a staple food, providing calories for 500 million people and constituting $37 \%$ of the population's dietary energy requirements. (IITA, 2010). Oriola and Raji, 2013; Ugwu and Ozioko, 2015 prescribe processing of cassava tuber into various staples such as gari, starch, flour, pellets and abacha as the best preservation method. Apart from the aforementioned shelf-stable products, cassava can be processed to other food products: biscuits, bread, lafun, baby food and industrial product: ethanol, livestock feed, gum, starch for adhesive, syrup concentrates for drinks, hydrolysates for pharmaceuticals, drugs, and seasoning (Aniedi et al., 2012; Ilori and Adetan, 2013). Also, it is an ingredient used for coagulation of rubber latex and manufacturing of dyes, chemicals and binder in textile industries (Kamal and Oyelade, 2010; Ugwu and Ozioko, 2015).

Various energy resources such as mechanical (machinery, human labour and animal draft), chemical fertilizer (pesticides, herbicides), electrical are used in agricultural production. (Vivek et al., 2010). Efficient use of energy resources is an important tool of sustainable agricultural production and eco-system (Jekayinfa et al, 2013). Ozturk I. (2010) and Payne J. E. (2010), studied the relationship between energy use efficiency and economic growth based on analysis of a broad empirical and statistical data of countries around the world, they concluded 
that economic output and energy consumption are linked. Also, Mousavi-Avval et al, 2011 reported that presently, productivity and profitability of agricultural production depends on level of energy consumption. Efficient use of energy resources reduces production costs, which boosts factor productivity and therefore economic growth (Vivid Economic, 2013).

Therefore, this study aims at determining the cost of energy resources used at each stages of production in cassava production, identify areas of high cost input which affect the productivity and evaluate the profitability of cassava production in Nigeria.

\section{Materials and Methods}

\subsection{Research Farms Used for Investigation}

The areas of study covered Oyo, Ogun, Osun and Kwara States of Nigeria. Ten (10) established farms were purposely selected for this research work. Four farms were selected in Oyo States, while two farms were surveyed in Ogun, Osun, and Kwara States.

\subsection{Cost Analysis Procedures}

Data on cost of energy resources, such as human labour, fuel, machinery, biological, N.P.K fertilizer and herbicide used for cassava production were obtained from selected farms through field surveys, direct measurements, interviews with farmers and structured questionnaires. The amounts of inputs used in the production of cassava were estimated based on unit operations.Mathematical expressions were used to obtain the amount spent on various stages of production. Data obtained were analysed statistically.

\subsection{Method of Cost Evaluation of Cassava Production}

To calculate the amount spent on each unit operation, quantitative data on operating conditions was required for each unit operation. The measured parameters for estimating amount spent on each unit operation are as shown in Table 1.

Table1. Measured Parameters for Evaluating Cost Input in Cassava Production

\begin{tabular}{|c|c|c|}
\hline $\mathbf{S} / \mathbf{N}$ & Operation & Required Parameter \\
\hline \multirow[t]{3}{*}{1} & Land preparing & Quantity of fuel used, 1. \\
\hline & & Number of person involved. \\
\hline & & Time taken for preparing the land, $\mathrm{h}$ \\
\hline \multirow[t]{2}{*}{2} & Stem harvesting & Time taken for stem cutting, $\mathrm{h}$ \\
\hline & & Number of person involved. \\
\hline \multirow[t]{3}{*}{3} & Planting & Number of person involved in planting. \\
\hline & & Time taken to plant the stem, $\mathrm{h}$ \\
\hline & & Quantity of stem required to plant 1 ha. \\
\hline \multirow[t]{3}{*}{5} & Fertilizer application & Number of person involved. \\
\hline & & Time taken to apply the fertilizer, $\mathrm{h}$ \\
\hline & & Quantity of fertilizer required, kg. \\
\hline \multirow[t]{3}{*}{6} & Inter - row Weeding & Number of person involved. \\
\hline & & Time taken for the weeding, $\mathrm{h}$ \\
\hline & & Quantity of chemical required, 1 \\
\hline \multirow[t]{2}{*}{7} & Harvesting & Number of person involved. \\
\hline & & Time taken for the harvesting, $\mathrm{h}$ \\
\hline \multirow[t]{2}{*}{8} & Transportation & Number of person involved. \\
\hline & & Time taken to load and offload cassava tubers, $\mathrm{h}$ \\
\hline
\end{tabular}

\section{Land Preparation}

The quantity of fuel used in land clearing, primary tillage, and secondary tillage was obtained from direct measurement in the farms. The cost of each operation was obtained by multiplying the total amount of fuel used in litres by the unit price of fuel, and the value obtained was added to the labour cost of the tractor operator. Land preparation cost was denoted as $C_{\mathrm{lc}}$ and calculated from equation 1 . 


$$
\left.C_{l c}=\left(\left(Q_{f} \times P_{f}\right)+C_{l}+C_{h m}\right)\right)
$$

Where:

$Q_{f}=$ Quantity of fuel used $(L)$

$P_{f}=$ price of fuel per litre ( $\left.\#\right)$

$C_{l}=$ Operator labour cost (\#)

$C_{h m}=$ Cost of hiring machinery ( $\left.\#\right)$

Unit price diesel fuel is $\$ 140.00$ per litre

\section{Stem Harvesting and Gathering}

The stem used for planting were either obtained from the previous season or purchased. The quantity of cassava stem required, cost of one bundle, number of people required to gather the stem, and their cost of labour were obtained. The cost stem was denoted has $C_{s g}$ and obtained from equation $2 \mathrm{a}$ and $2 \mathrm{~b}$.

When the stem was obtained from previous season

$$
C_{s g}=C_{l} \times N_{l}
$$

When the stem was purchased

$$
C_{s g}=\left(Q_{c b} \times C_{b}\right)
$$

Where:

$$
\begin{aligned}
& C_{l}=\text { Cost of labour per hectare }(\#) \\
& N_{l}=\text { No of labour required } \\
& Q_{c b}=\text { No of cassava stem bundles required } \\
& C_{b}=\text { Cost of one bundle }(\#)
\end{aligned}
$$

Unit price of stem bundle is 250

\section{Planting}

Planting was done manually with cutlass. Cassava was planted from stem cuttings of about $20 \mathrm{~cm}$ in length. The cost of labour for planting cassava stem per hectare was obtained from the farmer.

$$
C_{p}=\left(N_{l} \times C_{l}\right)
$$

\section{Weed Control}

Amount spent on weeding operation consists of manual and chemical energy (herbicide) cost. Data on quantity of herbicide, quantity of quantity of fuel, Cost of machinery, number of people involved and cost of labour per hectare was obtained and used in the computation of the cost. Cost of weeding was denoted as $C_{\mathrm{wc}}$ and calculated from Equations $4 \mathrm{a}$ and $4 \mathrm{~b}$.

When it is done using hoe

$$
\left.C_{\mathrm{w}}=\left(N_{p} \times C_{l}\right)\right\}
$$

When Knapsack sprayer is used

$$
C_{\mathrm{w}}=\left\{\left(N_{p} \times C_{l}\right)+\left(P_{h} \times Q_{h}\right)\right\}
$$

Where:

$Q_{h}=$ Quantity of herbicide (litre)

$C_{h}=$ Cost of herbicide ( $\# /$ litre)

The cost of 1 litre of herbicide or pesticide was $\$ 1200$

\section{Fertilizer Application}

Equation 5 was used to obtain the cost of applying fertilizer in various farms.

$$
C_{f e r}=\left\{\left(Q_{f e r} \times C_{f e r}\right)+C_{l}\right\}
$$

Where:

$Q_{f e r}=$ Quantity of fertilizer used $(\mathrm{Kg})$ 
$C_{\text {fer }}=$ Cost of fertilizer $(\# / \mathrm{kg}$

\section{Harvesting of cassava tubers}

The total cost of harvesting the cassava root per hectare was obtained from the farmers. It involves the cost of harvesting and de-stumping the cassava root. The cost was denoted as $C_{\mathrm{ch}}$.

$$
C_{c h}=\left(N_{l} \times C_{l}\right) \text {. }
$$

\section{Transportation}

Transportation cost was obtained from the labour cost of loading the cassava on the farm, off loading at the industry and the quantity of fuel used in the transportation. This was obtained from the equation 7.

$$
C_{t r}=\left\{\left(Q_{f} \times P_{f}\right)+\left(C_{h v}+C_{\text {load }}\right)\right\}
$$

Where:

$$
C_{\text {load }}=\text { labour cost of loading and off loading }
$$

\subsection{Economic Indicators}

Gross return, net income and benefit-cost ratio as economic indicators were calculated based on the existing price of the inputs and outputs. Gross return, net income and benefit-cost ratio were calculated using Equations 8 to 10 (Ozkan et al., 2004; Canakci et al., 2005):

$$
\text { Gross return }=(\text { Grain yield } \times \text { Grain price })(\$ / h a)
$$

The net income of production $=($ Gross return - Total Expenditure $)(\$ / \mathrm{ha})$

$$
\text { Benefit Cost Ratio }=\frac{\text { The net income of production }}{\text { Total expenditure per hectare }}
$$

\section{Results and Discussion}

\subsection{Result and Discussion}

The cost of energy inputs used in the production of cassava, total expenditure, gross return, and net income are shown in Table 1. It was observed that total expenditure per hectare varied from $\$ 64,698$ to $\$ 98,200$. The variation was due to the different amount of biological energy input, chemical energy input and difference in method of equipment acquisitions. Gross return and net income per hectare varied from $\$ 170,000$ to $\$ 240,000$ and $\$ 91,100$ to $\$ 154,202$, respectively. Variation in gross return and net income was due the variation in farm size, level of mechanization, quality of cassava cultivars used, and quantity of fertilizer applied.

The average total expenditure for cassava production per hectare was $\$ 82,055$, as shown in Table 2 . This is lower than $\$ 127,871$ and 113,554 obtained in Cross rivers and Akwa Ibom States of Nigeria by James et al., (2011) and Ebukiba (2010) for cassava production. Low expenditure for cassava production in this study was attributed to higher farm size and level of mechanisation. It was observed that in all the farms, the amount spent on manual energy resources was the highest. Averagely, the amount spent on manual energy was $\$ 35,056$ (42.72\%) of the total cost input, as shown Table 3. This value is lower than $\$ 83,370$ (65.2\%) obtained by James et al., (2011). Higher amount spent on labour by James et al., (2011) was attributed to low level of mechanisation. Farmers depend on hired labour for various farm operations which in turn increases the cost of production. The amount spent on biological energy (cassava stem) and machinery were $\$ 11,325(13.80 \%)$ and $\$ 11,200(13.65 \%)$, respectively, as shown in Table 3 and Figure 1. On nitrogen, phosphorus and potassium fertilizer, $\$ 6,141$ (7.48\%) was spent each. This was because, all the farmers in the study areas used NPK fertilizer of ratio 50:50:50. Generally in all the farms, the amount spent on agro-chemicals was the least. The average amount spent on agro-chemicals from the total cost was $\$ 1,470$ (1.79\%).

Operation wise, cost of inputs used in cassava production is shown in Table 3. The amount spent on fertilizer application was the highest in most of the farms and followed by land preparation. The average amount spent on fertilizer application and land preparation were $\$ 21,465$ (26.16\%) and $\$ 15,700$ (19.13\%) of the total expenditure, respectively as shown in Table 4 and Figure 2. High amount spent on fertilizer application and land preparation was attributed to high price of fertilizer and fuel in Nigeria. On stem gathering and planting operations, $\$ 13,305$ (16.21\%) was spent. Also, the average cost of harvesting and transporting the cassava tubers to the market were $\$ 13,420(16.35 \%)$ and $\$ 11,465$ (13.97\%), respectively. The least amount of $\$ 6700$ (8.16\%) was spent on weeding in the entire surveyed farm.

The average gross return obtained per hectare was $\$ 205,800$ as shown in Table 5. This was closer to $\$ 213,238$ obtained by Oduntan et al.,(2012) for cassava production in Ondo State, Nigeria. The average net income per hectare was $\$ 123,745$. This was similar to the findings by James et al., (2011) of ( $\$ 123,160)$. Ethah and Angba, 
(2016) obtained $\$ 137,869$, which was also relatively closer to the finding in this study. The benefit-cost ratio from cassava production was 2.50, as shown in Table 5, since this value is greater than 1 , cassava production in the area of study is a profitable venture. This value of benefit-cost ratio was compared and found to be consistent with findings reported by other authors for cassava production, such as 2.30 (Zaknayiba et al., 2014), 2.02 to 2.18 (Oduntan, et al., 2012) and 2.97 (NzehEmeka and Ugwu, 2014).

Table 2. Economic analysis of input energy in cassava production per hectare ( $\$$ ha)

\begin{tabular}{|c|c|c|c|c|c|c|c|c|c|c|}
\hline Energy resources & farm 1 & farm 2 & farm 3 & farm 4 & farm 5 & farm 6 & farm 7 & farm 8 & farm 9 & farm 10 \\
\hline Human Labour & 25720 & 30220 & 29200 & 31390 & 32615 & 27970 & 56502 & 32500 & 53300 & 31150 \\
\hline Machinery & 14000 & 14000 & 14000 & 14000 & 14000 & 14000 & - & 14000 & - & 14000 \\
\hline Fuel & 4480 & 7280 & 5600 & 4760 & 7000 & 4480 & 700 & 5600 & 700 & 5200 \\
\hline Agro- chemicals & 2000 & 1200 & 2000 & 1100 & 1000 & 2200 & 1000 & 2200 & 1000 & 1000 \\
\hline Nitrogen Fertilizer & 3666 & 7333 & 3666 & 5500 & 5500 & 5500 & 9166 & 5500 & 6416 & 9166 \\
\hline $\begin{array}{l}\text { Phosphorus } \\
\text { Fertilizer }\end{array}$ & 3666 & 7333 & 3666 & 5500 & 5500 & 5500 & 9166 & 5500 & 6416 & 9166 \\
\hline $\begin{array}{l}\text { Potassium } \\
\text { Fertilizer }\end{array}$ & 3666 & 7333 & 3666 & 5500 & 5500 & 5500 & 9166 & 5500 & 6416 & 9166 \\
\hline $\begin{array}{l}\text { Biological Energy } \\
\text { (cassava stem) }\end{array}$ & 11300 & 11000 & 10000 & 12500 & 10000 & 11750 & 12500 & 11750 & 11200 & 11270 \\
\hline Total expenditure & 64698 & 86699 & 71798 & 80250 & 81115 & 78900 & 98200 & 79550 & 89248 & 90098 \\
\hline $\begin{array}{l}\text { Gross return (yield } \\
\text { cost) }\end{array}$ & 200,000 & 240,000 & 226,000 & 190,000 & 224,000 & 170,000 & 220,000 & 184,000 & 184,000 & 220,000 \\
\hline Net return & 135302 & 153301 & 154202 & 109750 & 142885 & 91100 & 121800 & 104450 & 94752 & 129902 \\
\hline
\end{tabular}

Table 3. Average energy input cost in the production cassava from the farms ( $\mathbb{N} / \mathrm{ha})$

\begin{tabular}{ll}
\hline Input & Cost \\
\hline Human Labour & 35056 \\
Machinery & 11200 \\
Fuel & 4580 \\
Agro- chemicals & 1470 \\
Nitrogen fertilizer & 6141 \\
Phosphorous fertilizer & 6141 \\
Potassium fertilizer & 6141 \\
Biological energy (Cassava stem) & 11,326 \\
Total expenditure & 82,055 \\
\hline
\end{tabular}

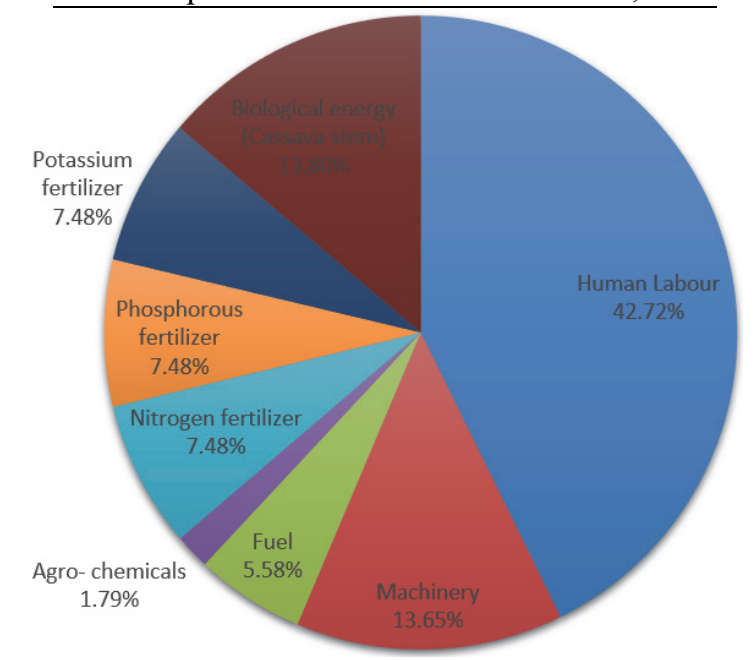

Figure 1. Pie Chat of the Energy Input Cost in the Production of Cassava 
Table 4. The operation -wise energy input cost in the production of cassava ( $\mathbb{N} / \mathrm{ha})$

\begin{tabular}{|c|c|c|c|c|c|c|c|c|c|c|}
\hline Operation & Farm 1 & Farm 2 & Farm 3 & Farm 4 & Farm 5 & Farm 6 & Farm 7 & Farm 8 & Farm 9 & Farm 10 \\
\hline Land preparation & 12000 & 14500 & 14000 & 15000 & 14000 & 12100 & 22000 & 15900 & 22400 & 15100 \\
\hline $\begin{array}{l}\text { Stem gathering and } \\
\text { planting }\end{array}$ & 13000 & 14000 & 11500 & 14550 & 12200 & 13000 & 14500 & 13500 & 13500 & 13300 \\
\hline Weeding & 4800 & 8500 & 8500 & 5500 & 6900 & 6500 & 8200 & 6000 & 4900 & 7200 \\
\hline Fertilizer application & 13398 & 25999 & 13398 & 19700 & 22015 & 19700 & 26000 & 19700 & 23248 & 31498 \\
\hline Harvesting & 12000 & 13000 & 13200 & 14000 & 13500 & 14500 & 14000 & 14000 & 13500 & 12500 \\
\hline Transportation & 9500 & 10700 & 11200 & 11500 & 12500 & 13100 & 13500 & 10450 & 11700 & 10500 \\
\hline Total expenditure & 64698 & 86699 & 71798 & 80250 & 81115 & 78900 & 98200 & 79550 & 89248 & 90098 \\
\hline Gross Return (yield cost) & 200,000 & 240,000 & 226,000 & 190,000 & 224,000 & 170,000 & 230,000 & 184,000 & 184,000 & 220,000 \\
\hline
\end{tabular}

Table 5. Average energy cost analysis of cassava production in each stage of production

\begin{tabular}{ll}
\hline Operation & Cost \\
\hline Land preparation & 15,700 \\
Stem gathering and Planting & 13,305 \\
Weeding & 6700 \\
Fertilizer application & 21,465 \\
Harvesting & 13,420 \\
Transportation & 11,465 \\
Total expenditure & 82,055 \\
\hline
\end{tabular}

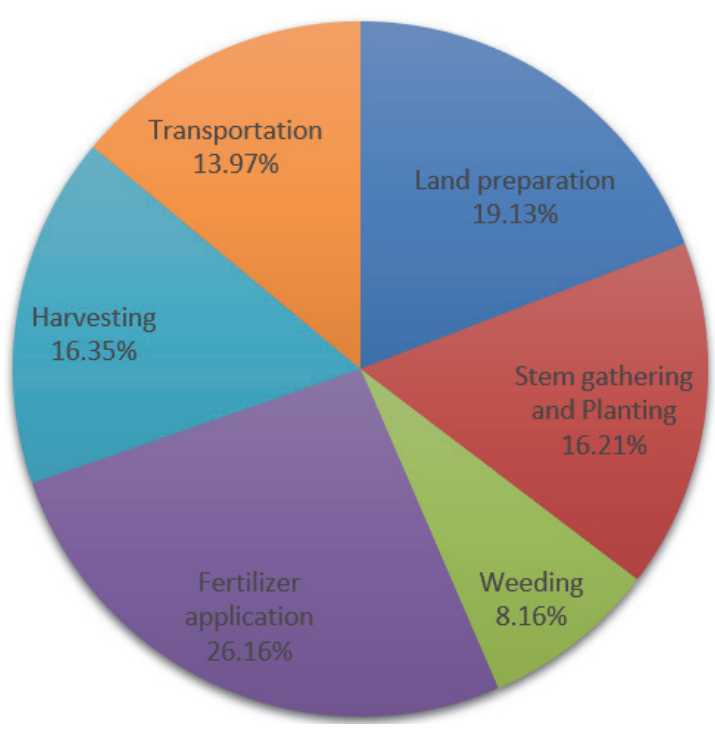

Figure 2. A pie chat of average energy cost analysis of cassava production in each stage of production

Table 5. Economic analysis of cassava production in Nigeria

\begin{tabular}{lll}
\hline Cost and return components & Unit & Value \\
\hline Total gross value of production (yield cost) & $\mathrm{ha}^{-1}$ & 205,800 \\
Total cost of production & $\mathrm{ha}^{-1}$ & 82,055 \\
Net income & $\mathrm{ha}^{-1}$ & 123,745 \\
Benefit cost ratio & - & 2.50 \\
\hline
\end{tabular}

\section{Conclusions}

The total cost of energy input in cassava production per hectare was $\$ 82,055$, with a profit margin of $\$ 123,745$.

Benefit cost ratio was 2.50 , indicating feasibility of cassava production from the economic point of view. 
Increasing the level of mechanization of the farms, using high yielding variety of stem and optimum use of fertilizer will further increase the profitability of cassava production.

\section{References}

Aniedi, O. E., Linus O. A., Ime A. E., \& Benjamin E. (2012). Mechanization of cassava peeling. Research Journal in Engineering and Applied Sciences, 1(5), 334-337.

Bamgboye, A. I., \& Kosemani, B. S. (2015). Energy Input in the Production of Cassava. Energy and Environment Research, 5(1), 42-48. http://dx.doi.org/10.5539/eer.v5n1p42

Canakci, M., Topakci, M., Akinci, I., \& Ozmerzi, A. (2005). Energy use pattern of some field crops and vegetable production: case study for Antalya region, Turkey. Energy Conversion and Management, 46, 655-66. https://doi.org/10.1016/j.enconman.2004.04.008

Ekubika, E. (2010). Economic analysis of cassava production farming in Akwalbom State, Nigeria. Journal of Agriculture, Biology. Animal sciences, 4(2), 24-31.

Ettah, O. I., Angba, \& Austine, O. (2016). Analysis of Cost and Returns among Cassava Farmers in Cross River State, Nigeria. International Journal of Science and Research (IJSR), 5(11), 111-114. https://doi.org/10.21275/ART20162150

FAO (Food and Agriculture Organization of the United Nations). (2013). FAOSTAT Online Statistical Database. Accessed on 01/07/2013. http://faostat.fao.org.

FAO, Statistics Division (FAOSTAT). (2015). Production statistics. Retrieved from https://faostat3.fao.org/download/Q/*/E

IITA 2010. Post-Harvest Technology". Annual report, 62-80.

Ilori, O. O., \& Adetan, D. A. (2013). A Study of the peel penetration pressure of two cassava varieties. African Institute for Science Policy and Innovation, Middle-East Journal of Scientific Research, 16(6), 884-889. https://doi.org/10.5829/idosi.mejsr.2013.16.06.11855

James, A., Nandi, P. G., \& Evans, N. Y. (2011). Economic Analysis of Cassava Production in Obubra Local Government Area of Cross River State, Nigeria. Asian Journal of Agricultural Sciences, 3(3), 205-209.

Jekayinfa, S. O., Afolayan S. O., Taiwo, A., \& Popoola J. O. (2013). Energy use efficiency of on- farm- and postpineapples production in Nigeria. International Journal of Energy Technology and Policy, 23(3), 234-67.

Kamal, A. R., \& Oyelade, O. A. (2010). Present status of cassava peeling in Nigeria. Journal of Agricultural Engineering and Technology, 18(2), 7-13. https://doi.org/10.12691/ajfst-5-6-2

Mousavi-Avval, S. H., Rafiee, S., Jafari, A., \& Mohammadi, A. (2011). Energy flow modeling and sensitivity analysis of inputs for canola production in Iran. Journal of Cleaner Production, 16, 1464-1470. https://doi.org/10.1016/j.clepro.2011.04.013

Nzeh, E. C., \& Ugwu, J. N. (2014). Economic analysis of production and marketing of cassava in Akoko North-West Local Government Area of Ondo State, Nigeria. International Journal of Agricultural Policy and Research, 2(6), 234-237.

Oduntan, O., Amos, T. T., \& Oseni, J. O. (2012). Efficiency and Profitability of Small-Scale Cassava Production in Akure Area of Ondo State, Nigeria. Applied Tropical Agriculture, 56-60.

Onyenwoke, C. A., \& Simonyan, K. J. (2014). Cassava post-harvest processing and storage in Nigeria: A review. African Journal of Agricultural Research, 9(53), 3853-3863. https://doi.org/10.5897/AJAR2013.8261

Oriola, K. O., \& Raji, A. O. (2013). Trends at mechanizing cassava postharvest processing operations. International Journal of Engineering and Technology (IJET), 3(9), 879-887. https://doi.org/10.12691/ajfst-5-6-2

Ozkan, B., Akaoz, H., \& Karadeniz, F. (2004). Energy requirement and economic analysis of citrus production in Turkey. Energy Convers. Manage, 45, 1821-1830. https://doi.org/10.3390/en20100001

Payne, J. E. (2010). Survey of the International Evidence on the Causal Relationship between Energy Consumption and Growth. Journal of Economic Studies, 37(1), 53-95. https://doi.org/10.1108/01443581011012261

Ralf, W., Jacobo, A., Cornelia, B., Bertha, S., Salim, A., Jesús, B., Paul, C., Hernan, C., Joe T., \& Peter, B. (2010). Provitamin A Accumulation in Cassava (Manihot esculenta) Roots Driven by a Single Nucleotide 
Polymorphism in a Phytoene Synthase Gene. The Plant Cell, 22, 3348-3356.

Shubo, L., Yanyan, C., Yuan, Z., Zhiting, L., Jidong, L., \& Mouming Z. (2017). The industrial application of cassava: current status, opportunities and prospects. Journal of the Science of Food and Agriculture, 97, 2282-2290. https://doi.org/10.1002/jsfa.8287

U.S. Department of Agriculture (USDA) 2015. Cost-Benefit Analysis of USAID/Nigeria's MARKETS II Program. February 24, 2014. Source: http:/usaid.gov/documents/1865/cost-benefitanalysis-usaidnigeria $\% \mathrm{E} 2 \% 80 \% 99$ s-markets-ii-program

Ugwu, K. C. and Ozioko, R. E. (2015). Development and performance test of cassava peeling and mashing machine. International Journal of Scientific and Engineering Research, 6(6), 1572-1579.

Vivek, K., Jyoti, P., Sachin, K., Dipak, B., \& Shilpa, D. (2010). Energy and Economic Evaluation of Farm Operations in Crop Production. Journal of Agricultural Science, 2(4), 191-200.

Vivid Economics. (2013). Energy Efficiency and Economic Growth. Report Prepared for The Climate Institute. Retrieved De. 28, 2016, from http://www.vivideconomics.com/publications/energy-efficiency-and-economic-growth

Zaknayiba, D. B., Agwale, A. O., \& Bello, D. (2014). Profitability Analysis of Cassava Production in Wamba Local Government Area of Nasarawa State, Nigeria. Production Agriculture and Technology Journal, 10(2), 218-224.

\section{Copyrights}

Copyright for this article is retained by the author(s), with first publication rights granted to the journal.

This is an open-access article distributed under the terms and conditions of the Creative Commons Attribution license (http://creativecommons.org/licenses/by/4.0/). 